\title{
PROFILE OF PATIENTS WITH URINARY INCONTINENCE IN A UNIVERSITY HOSPITAL OUTPATIENT CLINIC
}

\author{
Francisca das Chagas Sheyla Almeida Gomes Braga 1,* (D), Claudia Daniella Avelino Vasconcelos

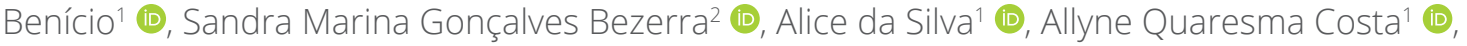 \\ Edvania Soares dos Santos ${ }^{1}$ [D, Roxana Mesquita de Oliveira Teixeira Siqueira' (1)
}

\begin{abstract}
Objective: to know the sociodemographic and clinical profile of people with urinary incontinence in an outpatient clinic of a University Hospital. Methods: cross-sectional study, using a semi-structured form with 63 women who were awaiting care at the gynecology and urology outpatient clinics, between the months of July and August 2019. The data were processed in the software Statistical Package for the Social Sciences - SPSS 20.0. Results: interviews were carried out with women aged between 19 and 77 years. Of these, $55.6 \%$ maintained an active sex life; $85.7 \%$ had pre-existing disease; $69.8 \%$ presented urinary loss when coughing, sneezing, smiling, putting on weight and/or making efforts; $12.7 \%$ need to urinate as soon as they feel like it; and $17.5 \%$ had loss of urine in both situations. About 35\% sought consultation due to low bladder and/or loss of urine; $27 \%$ had 4 to 5 pregnancies. Among the risk factors associated with urinary incontinence, $28.6 \%$ had diabetes mellitus, $61.9 \%$ had arterial hypertension, $82.5 \%$ used continuous medication, $11.1 \%$ was obese, $34.9 \%$ reported constipation problems and 74.6\% underwent pelvic surgery. Conclusion: it was concluded that all women in the study had more than one risk factor for developing urinary incontinence, reinforcing their multifactoriality, as well as the importance of a holistic and multiprofessional treatment.
\end{abstract}

DESCRIPTORS: Nursing. Urinary incontinence. Health profile. Prevalence. Stomatherapy.

\section{PERFIL DE PACIENTES COM INCONTINÊNCIA URINÁRIA EM UM AMBULATÓRIO DE HOSPITAL UNIVERSITÁRIO}

\section{RESUMO}

Objetivo: conhecer o perfil sociodemográfico e clínico das pessoas com incontinência urinária em ambulatório de Hospital Universitário. Métodos: estudo transversal, em que se utilizou formulário semiestruturado com 63 mulheres que aguardavam atendimento nos ambulatórios de ginecologia e urologia, entre os meses de julho e agosto de 2019. Os dados foram processados no software Statistical Package for the Social Sciences - SPSS 20.0. Resultados: foram realizadas entrevistas com mulheres com idade entre 19 e 77 anos. Dessas, 55,6\% mantinha vida sexual ativa; 85,7\% apresentava doença preexistente; 69,8\% presentou perda urinária ao tossir, espirrar, sorrir, colocar peso e/ou fazer esforços; $12,7 \%$ precisa urinar assim que sentem vontade; e 17,5\% apresenta perda de urina nas duas situações. Cerca de 35\% procurou consulta devido à bexiga baixa e/ou perda de urina; $27 \%$ teve de 4 a 5 gestações. Dentre os fatores de risco associado à incontinência urinária, 28,6\% tinha diabetes mellitus, $61,9 \%$ hipertensão arterial, 82,5\% fazia uso de medicação contínua, 11,1\% era obesa, 34,9\% relatou problemas de

1. Universidade Federal do Piauí - Centro de Ciências da Saúde - Departamento de Enfermagem - Teresina (PI), Brazil. 2. Universidade Estadual do Piauí - Centro de Ciências da Saúde - Departamento de Enfermagem - Teresina (PI), Brazil. *Correspondence author: sheylagomesbraga@gmail.com

Section Editor: Gisela Maria Assis

Received: Dez. 14, 2020 | Accepted: Fev. 20, 2021

How to cite: Braga FCSAG; Benício CDAV; Bezerra SMG; Silva A; Costa AQ; Santos ES; Siqueira RMOT. Profile of patients with urinary incontinence in a university hospital outpatient clinic. ESTIMA, Braz. J. Enterostomal Ther., 2021, 19: e0721. https://doi. org/10.30886/estima.v19.997_IN 
constipação e 74,6\% fez cirurgias pélvicas. Conclusão: concluiu-se que todas as mulheres do estudo apresentaram mais de um fator de risco para desenvolver incontinência urinária, reforçando sua multifatorialidade, bem como a importância de um tratamento holístico e multiprofissional.

DESCRITORES: Enfermagem. Incontinência urinária. Perfil de saúde. Prevalência. Estomaterapia.

\title{
PERFIL DE LOS PACIENTES CON INCONTINENCIA URINARIA EN UNA CLÍNICA AMBULATORIA DE UN HOSPITAL UNIVERSITÁRIO
}

\begin{abstract}
RESUMEN
Objetivo: Conocer el perfil sociodemográfico y clínico de personas con incontinencia urinaria en una consulta externa de un Hospital Universitario. Métodos: El estudio transversal, se utilizó un formulario semiestructurado con 63 mujeres que se encontraban en espera de atención en las consultas externas de Ginecología y Urología, entre los meses de julio y agosto de 2019. Los datos se procesaron mediante el Paquete Estadístico de la Ciencias sociales: software SPSS. Resultados: Se realizaron entrevistas con mujeres,; edad entre 19 y 77 años; mantuvieron una vida sexual activa 55,6\% y 85,7\% tenían enfermedad preexistente. Presentaron pérdidas urinarias al toser, estornudar, sonreír, engordar y/o realizar esfuerzos 69,8\%; El 12,7\% necesita orinar tan pronto como le apetece y el 17,5\% tiene pérdida de orina en ambas situaciones. Aproximadamente el 35\% buscó consulta debido a la disminución de la vejiga y / o la pérdida de orina; El 27\% tuvo de 4 a 5 embarazos. Entre los factores de riesgo asociados a la incontinencia urinaria, el 28,6\% tenía diabetes mellitus, el 61,9\% hipertensión arterial, el 82,5\% usaba medicación continua; El $11,1 \%$ eran obesos; $34,9 \%$ informó problemas de estreñimiento; El 74,6\% se sometió a cirugía pélvica. Conclusión: Se concluye que todas las mujeres del estudio tenían más de un factor de riesgo para desarrollar IU, reforzando su multifactorialidad, así como la importancia de un tratamiento holístico y multiprofesional.
\end{abstract}

DESCRIPTORES: Enfermería. Incontinencia urinaria. Perfil de salud. Prevalencia. Estomaterapia.

\section{INTRODUCTION}

The International Continence Society (ICS) defines urinary incontinence (UI) as the involuntary loss of urine. Although considered a priority health issue, UI is underreported and underdiagnosed, with low professional recognition. In 1998 it became part of the International Classification of Diseases (ICD), ceasing to be considered just a symptom and becoming a disease ${ }^{1}$.

According to the Sociedade Brasileira de Urologia (SBU), this condition affects around 400 million people worldwide, and in Brazil there are an average of 10 million people with incontinence ${ }^{2}$. Even though it is more common in women, it affects the population, regardless of sex, ethnicity or age. It has an increasing prevalence, as the population age increases ${ }^{3-5}$.

Among general population studies, the prevalence of UI varied between $25 \%$ and $45 \%$ in adult women, and in adult men there were publications with variations between $1 \%$ and 39\%, with the proportion in women being at least twice as high when compared to men, that is, $2: 1$. There is no standardization of tools and methods used in prevalence studies that define UI in practice, which can make the variation of prevalence wide, since it is still poorly established ${ }^{6}$.

In Brazil, there are few studies on the prevalence of UI, most of which are aimed only at women. Among the studies found, one conducted with adults from the urban population of Pouso Alegre, Minas Gerais, concluded that 20.1\% of the general population has UI. Among women and men, the prevalence was $32.9 \%$ and $6.2 \%$, respectively, with a proportion of approximately $5: 1^{7}$.

In Piauí, the prevalence of UI is not known, however a study carried out in 2016 with women in primary care in Teresina, showed that of the 306 study participants, 40.8\% (125) were incontinent ${ }^{8}$. 
Corroborating the aforementioned studies, the 2018 National Consensus on Urogynecology presented the prevalence of the most common types of UI, in which stress urinary incontinence (SUI) has a prevalence of 10 to $39 \%$, with the highest rate, followed by mixed urinary incontinence (MUI) with 7.5 to $25 \%$. Isolated urinary incontinence (IUI) is the least frequent and corresponds to 1 to $7 \%$. The other causes of incontinence have an estimated prevalence of 1 to $7 \%^{2}$.

UI has a profound negative impact on the well-being and quality of life of people affected, which often leads to social embarrassment, reduced employment, decreased productivity at work, affects sexual life, in addition to presenting a significant economic and health burden ${ }^{6}$.

People with UI benefit when exposed to specific treatment through nursing interventions, however most people are unaware of this information because it is a poorly reported dysfunction in the health area and in the media, which makes it difficult to clarify and identify by the population of such condition?

Thus, knowing the high prevalence of UI worldwide, as well as the interest in identifying the main aspects of people with UI attended at a public institution in Piauí, in order to develop actions with the population of the State, the following question arose: which is the sociodemographic and clinical profile of people with UI treated at the urology and gynecology outpatients of the University Hospital?

Thus, the study aimed to characterize the sociodemographic and clinical profile of people with UI treated at the gynecology and urology outpatients of Hospital Universitário. These data supported the development of educational technology for adults and will contribute to the development of care strategies to be provided to the population of the State, while also subsidizing the construction of an institutional protocol for outpatient care for people with UI.

\section{METHOD}

Descriptive, analytical and cross-sectional study regarding the characterization of the profile of patients with UI treated at an outpatient clinic of a University Hospital located in Teresina, PI. Among the existing specialties, the institution has urology and gynecology services, as well as an outpatient stomatherapy and other multidisciplinary specialties.

The urology service performs urofluxometry exams and urodynamic studies, consultations and surgeries. In 2018, around 156 consultations were carried out per month, totaling 1,874 consultations per year. The gynecology service, on the other hand, takes place at the women's health outpatient clinic, where consultations and examinations of oncotic colpocytology, colposcopy, hysteroscopy and urodynamic evaluation are carried out, in addition to surgeries. In 2018, approximately 602 calls were made per month, totaling 7,224 per year.

The population consisted of patients treated at the outpatient clinic for the specialties of gynecology and urology. The sample was determined by the following inclusion criteria: men and women who were awaiting consultation for the specialties of gynecology or urology, aged 18 and over at the time of the interview, complaining of involuntary loss of urine. Exclusion criteria were: users who were waiting for care without a complaint of urinary loss and people with cognitive impairment that made it impossible to answer the form.

Were approached 339 patients who were awaiting consultations at the gynecology and urology services. Of these, 76 reported having symptoms of UI, but 13 people refused to participate. Thus, the sample consisted of 63 participants in total. Data were collected using a semi-structured form, previously validated by Benício $(2018)^{10}$ and Favoretto $(2015)^{11}$, and adapted with questions concerning the proposed objectives, containing information about the sociodemographic, economic, clinical condition and risk factors related to the theme. The collections took place in the morning and afternoon shifts, between the months of July and August 2019. The interviewees answered verbally to the researcher's questions without interference in their answers.

To conduct the interviews, the participants were initially approached about the existence or not of incontinence. If so, the patient was invited to participate in the research, and formalizations were carried out, explaining the objectives, 
risks and benefits. In case of agreement, the participants were taken to a reserved space, such as doctor's offices or a waiting room. Then, they received more information about the study and, those who agreed to participate, signed the Free and Informed Consent Form.

The data were submitted to a typing process, using spreadsheets from the Microsoft ${ }^{\circledR}$ Excel $^{\circledR}$ application version 16.0 and later exported to the Statistical Package for the Social Sciences- SPSS version 20.0. The sociodemographic, clinical profile and associated risk factors were presented in tables and described using absolute and percentage frequencies. Some clinical data were also outlined using descriptive statistics: mean and standard deviation.

The study respected the guidelines of Resolution No. 466/2012 of the National Health Council (Conselho Nacional de Saúde/CNS), which deals with research involving human beings, preserving the anonymity, privacy and confidentiality of those involved. The study is part of a macro project entitled "Good practices in nursing care for hospitalized patients: technologies to measure, implement and evaluate”, which was submitted to the Research Ethics Committee ( Comitê de Ética em Pesquisa/CEP) of the Universidade Federal do Piauí (UFPI), under CAAE 01564818.2.0000.5214 and approved by Opinion No. 3,305,182.

\section{RESULTS}

\section{Sociodemographic profile}

Analyzing the sociodemographic profile of the 63 participants, all were female; with an average age of $52.1 \pm 13.4$ years; the majority being brown $(77.8 \%)$, followed by black $(9.5 \%)$ and white $(7.9 \%)$. As for education, most had incomplete primary education (39.7\%); in relation to occupation, $30.2 \%$ had a job, $27 \%$ were retired; and $12.7 \%$ did not perform any activity; with individual or family income of up to 1 minimum wage it was 55.6\%; among those who had an income of up to 1 minimum wage, $43 \%$ supported 4 people. When asked about their marital status, the majority were married (63.5\%), and the rest lived in a stable relationship or were single, both situations with 11.1\%. Data shown in Table 1.

Table 1. Sociodemographic profile of participants with urinary incontinence treated at an outpatient clinic of a University Hospital (n=63). Teresina (PI), Brasil - 2019.

\begin{tabular}{lc}
\hline Variables & $\mathbf{n}(\%)$ \\
\hline Gender & $0(0)$ \\
\hline Male & $63(100)$ \\
\hline Female & $49(77.8)$ \\
\hline Colour & $6(9.5)$ \\
\hline Brown & $5(7.9)$ \\
\hline Black & $3(4.8)$ \\
\hline White & $2(3.2)$ \\
\hline Other & $25(39.7)$ \\
\hline Education & $9(14.2)$ \\
\hline Not literate & $3(4.8)$ \\
\hline Incomplete elementary school & $17(27)$ \\
\hline Complete elementary school & $2(3.2)$ \\
\hline Incomplete high school & $5(7.9)$ \\
\hline Complete high school &
\end{tabular}


Table 1. Continuation...

\begin{tabular}{|c|c|}
\hline Variables & $\mathrm{n}(\%)$ \\
\hline \multicolumn{2}{|l|}{ Occupation } \\
\hline None & $8(12.7)$ \\
\hline Retired & $17(27)$ \\
\hline Housewife & $14(22.2)$ \\
\hline Rural worker & $5(7.9)$ \\
\hline Formal employment & $19(30.2)$ \\
\hline \multicolumn{2}{|l|}{ Income } \\
\hline Up to 1 minimum wage & $35(55.6)$ \\
\hline Between 1 and 2 minimum wages & $14(22.2)$ \\
\hline Between 2 and 3 minimum wages & $9(14.3)$ \\
\hline Between 3 and 4 minimum wages & $5(7.9)$ \\
\hline \multicolumn{2}{|l|}{ Number of Dependents } \\
\hline One & $7(11.1)$ \\
\hline Two & $16(25.4)$ \\
\hline Three & $15(23.8)$ \\
\hline Four & $10(15.9)$ \\
\hline Five & $4(6.3)$ \\
\hline More than five & $11(17.5)$ \\
\hline \multicolumn{2}{|l|}{ Marital status } \\
\hline Single & $7(11.1)$ \\
\hline Married & $40(63.5)$ \\
\hline Widow & $6(9.5)$ \\
\hline Separated & $3(4.8)$ \\
\hline Stable union & $7(11.1)$ \\
\hline TOTAL & $63(100)$ \\
\hline
\end{tabular}

\section{Clinical profile}

According to Table 2, in the topic related to active sexual life, 55.6\% maintained an active sexual life and $44.4 \%$ did not have sexual intercourse. Of these, $55.6 \%$ reported that UI did not interfere with sex life and $6.3 \%$ reported that it did. Regarding the existence of a pre-existing disease, $85.7 \%$ had a disease in addition to incontinence.

When asked about the time he has been experiencing urine loss, it was possible to observe an average time of $5.8 \pm 9.5$ years, the shortest reported time was 0.16 years ( 2 months) and the longest 66 years, the median time was 3 years, that is, $50 \%$ started losing urine 3 years ago.

Regarding the loss of urine, the largest number of respondents, $69.8 \%$, reported having loss when coughing, sneezing, smiling, putting on weight and/or making an effort; $12.7 \%$ need to pee as soon as they feel like it, otherwise they do it on clothes; and $17.5 \%$ had loss of urine in the two previous situations.

In the report of the participants regarding their main complaint for the consultation that day at the service, a low bladder and/or loss of urine stood out, with 34.9\%, followed by an appointment for surgery or post-surgical return, with $17.5 \%$.

As for the gynecological history, $41.3 \%$ had 1 to 3 pregnancies; $20.6 \%$ more than 6 pregnancies; and $11.1 \%$ never got pregnant. With regard to the occurrence of abortion, $39.7 \%$ reported having had at least one case of abortion.

Regarding the number and type of delivery per person, it is observed that, of the total participants, $11.1 \%$ had no delivery; $31.7 \%$ had 1 to 3 normal births and no cesarean section; $19 \%$ had 4 to 6 normal deliveries and no cesarean section; 7.9\% had 7 or more normal births and no cesarean section; $15.9 \%$ had 1 to 3 normal births and 1 cesarean section; $4.8 \%$ 
had 4 to 6 normal births and 1 cesarean section; $1.6 \%$ had 7 normal births and 1 cesarean section; $4.8 \%$ had 1 to 3 normal deliveries and 2 cesarean deliveries; and $4.8 \%$ had 1 to 3 normal deliveries and 3 cesarean deliveries.

Table 2. Clinical profile and gynecological history of participants with urinary incontinence treated at a University Hospital $(n=63)$. Teresina (PI), Brasil - 2019.

\begin{tabular}{|c|c|}
\hline Variables & $\mathrm{n}(\%)$ \\
\hline \multicolumn{2}{|l|}{ Active sex life } \\
\hline Yes & $35(55.6)$ \\
\hline No & $28(44.4)$ \\
\hline \multicolumn{2}{|l|}{ Incontinence hinders sex life } \\
\hline Yes & $4(6.3)$ \\
\hline No & $35(55.6)$ \\
\hline Not applicable & $24(38.1)$ \\
\hline \multicolumn{2}{|l|}{ Has any associated disease } \\
\hline Yes & $37(58.7)$ \\
\hline No & $26(41.3)$ \\
\hline Urine loss time & $5.8 \pm 9.54^{*}$ years \\
\hline \multicolumn{2}{|l|}{ Situation in which there is loss of urine } \\
\hline $\begin{array}{l}\text { When coughing, sneezing, smiling, putting on weight and/or } \\
\text { making an effort }\end{array}$ & $44(69.8)$ \\
\hline Need to pee as soon as feeling like it, otherwise will do it on clothes. & $8(12.7)$ \\
\hline Presents the two options above. & $11(17.5)$ \\
\hline \multicolumn{2}{|l|}{ Main complaint on the consultation } \\
\hline Hemorrhage & $4(6.3)$ \\
\hline Neoplasm & $4(6.3)$ \\
\hline Surgery or post-surgery return & $11(17.5)$ \\
\hline Breast problems & $3(4.8)$ \\
\hline Show or take exams & $9(14.3)$ \\
\hline Low bladder and/or loss of urine & $22(34.9)$ \\
\hline Abdominal pain & $10(15.9)$ \\
\hline \multicolumn{2}{|l|}{ Number of pregnancies } \\
\hline None & $7(11.1)$ \\
\hline From 1 to 3 & $26(41.3)$ \\
\hline From 4 to 5 & $17(27)$ \\
\hline Six or more & $13(20.6)$ \\
\hline \multicolumn{2}{|l|}{ Abortion } \\
\hline Yes & $25(39.7)$ \\
\hline No & $38(60.3)$ \\
\hline TOTAL & $63(100)$ \\
\hline
\end{tabular}

*Mean \pm standard deviation.

\section{Risk factors}

As for the risk factors that may be associated with UI (Table 3), observing the positive responses, it can be seen that $1.6 \%$ had neurological disease; there was no case of chronic obstructive pulmonary disease (COPD); $28.6 \%$ were diagnosed with diabetes mellitus; $61.9 \%$ with arterial hypertension; $1.6 \%$ were smokers; $76.2 \%$ used caffeine; $82.5 \%$ used some medication for continuous use; $28.6 \%$ used antidiabetic agents; $61.9 \%$ used antihypertensive drugs; $11.1 \%$ were obese; $34.9 \%$ reported constipation problems; $74.6 \%$ have already had pelvic surgery; and $23.8 \%$ had abdominal surgery. 
Table 3. Distribution of participants with urinary incontinence treated at a University Hospital, according to associated risk factors ( $n=63)$. Teresina (PI) - 2019.

\begin{tabular}{lc}
\hline Variables & $\mathbf{n}(\%)$ \\
\hline Neurological disease & $1(1,6)$ \\
\hline COPD & $0(0)$ \\
\hline Diabetes mellitus & $13(20,6)$ \\
\hline Systemic arterial hypertension & $29(46)$ \\
\hline Tabagism & $1(1,6)$ \\
\hline Caffeine & $48(76,2)$ \\
\hline Medications & $14(22,2)$ \\
\hline Antidiabetics & $18(28,6)$ \\
\hline Antihypertensive drugs & $39(61,9)$ \\
\hline Obesity & $7(11,1)$ \\
\hline Constipation & $22(34,9)$ \\
\hline Pelvic surgeries & $47(74,6)$ \\
\hline Abdominal surgeries & $15(23,8)$ \\
\hline CopD =Chronic obstructive pulmonary disease.
\end{tabular}

\section{DISCUSSION}

\section{Sociodemographic profile}

The study was carried out only with people who had UI and although there were attempts to collect it in the gynecology and urology outpatient clinics in search of information about both genders, the work was carried out only with women. It is believed that among the reasons are the fact that consultations in the gynecology sector take place daily in two shifts and in urology only three times a week, in a total of four weekly visits, and that it also serves women. Another reason is the better acceptance of women to participate in research, and also because there are more women affected by this condition, in addition to being the public that most seeks health services.

It can be said that women use health services more than men. This statement is justified, in part, by the variations in the profile of health needs between genders, the main reasons being pregnancy and childbirth, and the greater interest of women in their health. ${ }^{12}$.

When age is analyzed, it can be seen that the majority has an average age of 52 years, which corroborates the literature on the subject, demonstrating a directly proportional relationship between age and UI, and this increase reaches its maximum level in middle age, with a prevalence of $30 \%$ to $40 \%$, maintaining elevation as age increases ${ }^{13}$. In studies on prevalence, they presented statistically relevant data between the age group and the occurrence of UI, demonstrating that age alone does not cause incontinence, but induces structural and functional changes in the urinary system that predisposes to the problem ${ }^{8,14}$.

The study showed a greater number of brown women with UI symptoms, followed by black and white women, which corroborates the research that characterized the population of Piauí, with brown color as the most prevalent, in $72.9 \%$ of the population. This is reinforced by an important fact related to skin color, Brazil is a mixed country and the brown color is predominant ${ }^{8,15}$.

As for education, most had little time at school, having only incomplete elementary education, but there was a reasonable distribution across all levels of education. Regarding occupation, the majority worked in a job outside or at home, followed by retirees. Income with a higher percentage represented participants who earned between one and two 
minimum wages. Analyzing the percentage of people who are supported by this income, the individual distribution becomes low.

According to a study carried out by the Brazilian Institute of Geography and Statistics (Instituto Brasileiro de Geografia e Estatística/IBGE), half of adult Brazilians did not attend school beyond elementary school, with approximately $35 \%$ not having completed elementary school. Brazil's per capita household income (per person) was around R $\$ 1,373$ in 2018, with Piaui's income being $\mathrm{R} \$ 817$ per person ${ }^{16}$. This corroborates the characteristic presented in this research, with the majority of participants having an income below the Brazilian average. However, it is not possible to affirm in this study the relationship between economic condition and the presence of incontinence.

\section{Clinical profile}

The marital status of the interviewees showed that the majority live with a partner, married or in a stable relationship. The findings showed that more than half have an active sex life, however a significant number of women who no longer have an active sex life can be perceived, even having a partner. Most reported that UI does not interfere with sexual life and a small percentage admit to impairment in this regard. This fact does not invalidate the importance of the problem and the need for interventions with these women.

One of the fields of life affected by UI is sexuality, which is rarely addressed, but involves the subjectivity of the human being in its social, cultural, ideological, beliefs and experiences, and can be affected, added to the sexual act itself, since it a late approach can have consequences such as a complete abdication of sexual life ${ }^{17}$.

Regarding the preexistence of some disease, the majority presented one or more diseases in addition to incontinence. Diseases that in the literature demonstrate to be part of the risk factors for the individual to develop UI.

As for the reason for urinary loss, losses caused by coughing, sneezing, smiling, putting on weight and/or making efforts were predominant, these symptoms being more related to stress incontinence, which corroborates the studies on the subject, which had SUI as the most prevalent in all studies analyzed ${ }^{4,7,8}$.

SUI occurs due to the increase in intra-abdominal pressure without the previous perception of the urge to urinate. With the increase in abdominal pressure and failure in the continence mechanisms when coughing, sneezing and lifting weight, urine loss occurs. Severity is also a relational factor with the amount of urinary loss ${ }^{7}$.

The study focused on participants who had UI symptoms. When asked about the main complaint for the consultation that day at the service, around 1/3 reported a low bladder and/or loss of urine, the rest were awaiting consultation for other problems and many, during the interview, did not they knew whether or not they valued the UI problem as something to be treated, although there was discomfort in the face of the condition presented.

The result is confirmed by the literature that shows the embarrassment of the participants when talking about the subject, leading one in three people who have incontinence not to seek health services for this reason, reinforcing the discussions on the subject, knowing that most of the time, people live with the problem for long years and evaluate it as normal ${ }^{18}$.

A study on the treatment of incontinence in elderly women reports that women perceive incontinence as being a natural process of aging and, due to lack of information, out of shame they do not seek the health service for the treatment of UI, therefore using, diapers or sanitary napkins as a method of care, which is worrying, as it can interfere with sexual life, physical and domestic activities and work ${ }^{17,18}$.

In the obstetric history, it is possible to observe the predominance of multiple pregnancies and vaginal deliveries, corresponding, respectively, to almost half of the first and most of the second. The sum of women who had four or more births represented an important number and of these, few had any cesarean delivery. Thus, the study corroborates other studies that show the impact of pregnancy and, mainly, of normal delivery as a predisposing factor for UI.

The research is consistent with other prevalence studies carried out that showed pregnancy as a risk factor, since the first pregnancy, increasing with the subsequent ones, and that normal birth increases the chance of developing incontinence. In a population study on UI during pregnancy, the prevalence of UI during pregnancy was $14.7 \%$ in primiparous women and the likelihood of UI occurring varied significantly according to the characteristics of women, such as age, weight and 
exercise physicists ${ }^{19}$. And with the occurrence of multiple pregnancies the predisposition to UI increases even more ${ }^{20}$. In other research it can be observed that the risk of developing UI is greater after vaginal delivery (71\%) than after cesarean section, and the prevalence of UI over ten years, almost tripled after vaginal delivery compared to cesarean section ${ }^{21}$.

\section{Risk factors}

There are several risk factors known to be associated with UI, which were investigated in this study. An integrative review on UI prevention in elderly women reinforces that in addition to advancing age, other factors may predispose to the development of UI, which are: diabetes, obesity, smoking, menopause, diseases of the central nervous system, use of medications, restricted mobility, multiple vaginal deliveries, fecal impaction, psychic disorders, decreased tonus in the perineal region and alcohol use ${ }^{21}$. And it is these associated factors that increase the possibility of their occurrence.

In the study, one can observe the existence of one or more of these factors present in the research participants.

Arterial hypertension was identified in a significant amount in the study, whereas diabetes mellitus appeared in a smaller proportion. It can be seen in the study that patients with diabetes usually have hypertension and use one or more medications for one or both diseases. Studies on the prevalence of climacteric and on the characterization of incontinent women in a gynecology clinic also did not show, in their results, a significant relationship between the two diseases and $\mathrm{UI}^{20,22}$.

It was obtained a percentage of people who use caffeine and/or who underwent pelvic surgeries, followed by constipation problems, abdominal surgeries and obesity/overweight, to a lesser extent. Caffeine is a bladder irritant and products with the presence of the substance can increase the need to urinate. Intestinal constipation can affect urological function by compressing the bladder when stretching of the rectum occurs and by the effort made in the evacuation, which can cause injury to the pelvic muscles ${ }^{20}$. Gynecological surgeries and episiotomy can cause deformities in the pelvic floor, and overweight and obesity increase abdominal pressure. All of these factors can predispose to involuntary loss of urine ${ }^{22}$.

It is pointed out that the same participant has one or more risk factors for the development of UI. It is believed that an isolated factor does not lead to UI, but rather the sum of determining and conditioning factors. Which leads to reinforce multifactoriality for the presence of UI.

Regarding limitations, the study did not have a male sample, although the initial proposal was to encompass both genders. This was due to the reduced flow of male patients, the non-acceptance to participate in the research, as well as the time available to complete the study, which decreased the chance of conducting an interview with both genders and made it impossible to cross these data. Another factor that can be considered limiting was the performance of the study only with people who reported UI symptoms, not allowing the comparison of data between people without and with UI.

Further profile studies are recommended in Brazil and Piauí, with a larger sample size and with more variables to obtain information that can support new interventions and the implementation of services.

The study proved to be an important contributor to profile research, as it reinforces and increases information on the subject and its epidemiological aspects. It is also possible to observe the importance of knowing the profile of incontinent patients in the institution so that strategies for the care and treatment of this clientele can be developed, as well as subsidizing new works.

\section{CONCLUSION}

With the study it can be evidenced that the participants have as characteristics to be, mostly, brown, predominant color in this region of the country. With an average age of 52 years and with low schooling. Most have income, however they are responsible for the family's livelihood, which makes the per capita value low.

The largest number of women presented SUI, followed by MUI and IUI, respectively. Around 1/3 of these women sought outpatient services for the treatment of voiding dysfunctions, which demonstrates the demand for the treatment of UI in this institution. 
Most of the interviewees had multiple pregnancies, in addition to other risk factors that appeared significantly in the study, which were arterial hypertension, continuous use of medications, especially antihypertensive drugs, and have already undergone pelvic surgery. To a lesser extent, but still with a certain predominance, people with diabetes and using antidiabetic drugs appeared, with constipation problems and who have already undergone abdominal surgery.

Thus, it is possible to conclude that all women in the study had more than one risk factor for developing UI, reinforcing their multifactoriality, as well as the importance of a holistic and multiprofessional treatment.

When emphasizing the objective of knowing the profile of the patients, although with a small sample result, in view of the estimate of the population with this dysfunction, it presented satisfactory results and consistent with the existing literature, since the data referring to age, education, family income and race/color, as well as obstetric history and associated risk factors corroborate national and international studies carried out on the subject.

The number of women who have their sex life with some degree of interference due to UI, even in a not very significant amount in this study, should be valued, as well as the neglect in seeking treatment due to lack of knowledge about the problem and/or the possibility of treating it.

\section{AUTHORS' CONTRIBUTION}

Conceptualization: Braga FCSAG and Benício CDAV; Methodology: Braga FCSAG and Benício CDAV; Research: Braga FCSAG, Silva A, Costa AQ and Santos ES; Writing - First version: Braga FCSAG and Siqueira RMOT; Writing Review \& Editing: Braga FCSAG, Benício CDAV and Bezerra SMG; Resources: Braga FCSAG; Supervision: Braga FCSAG.

\section{DATA STATEMENT AVAILABILITY}

Data will be made available upon request.

\section{ACKNOWLEDGEMENTS}

We thank all the participants in the research, their contribution was essential to achieve our goals. Thanks.

\section{REFERENCES}

1. Brasil DM, Nicolau Al, Bilhar AP, Karbage AS, Lucena SV, Carmo TF et al. Incontinência urinária e função sexual feminina: revisão integrativa de questionários validados. Acta paul. Enferm. 2018; 31(5): 558-563. https://doi.org/10.1590/1982-0194201800077

2. Sociedade Portuguesa De Ginecologia. Consenso Nacional sobre Uroginecologia Incontinência Urinária de Esforço: Um perfil da clientela, junho de 2018 - Secção Portuguesa de Uroginecologia.

3. Riemsma R, Hagen S, Kirschner-Hermanns R, Christine N, Helle W, Karl-Erik A et al. A incontinência pode ser curada? Uma revisão sistemática das taxas de cura. BMC Med.2017; 15: 63. https://doi.org/10.1186/s12916-017-0828-2

4. Benício CDAV, Luz MHBA, Carvalho NV, Brito BAM, Ferreira JLS. Conhecimento de Mulheres Incontinentes sobre Incontinência Urinária: uma Reflexão Teórico Crítica. Estima-Brazilian Journal of Enterostomal Therapy. 2017; 15(1): 58-61. https://doi. org/10.5327/Z1806-3144201700010010

5. Junqueira JB, Santos VLCG. Incontinencia urinaria en pacientes hospitalarios: prevalencia y factores asociados. Rev. Latino-Am. Enfermagem [Internet]. 2017; 25: e2970. https://doi.org/10.1590/1518-8345.2139.2970

6. Abrams P, Cardozo L, Wagg A, Wein A. Incontinence. 6th International Consultation on Incontinence. International Contnence Society. Tokyo. 2017.

7. Santos CRS, Santos VLCG. Prevalência da incontinência urinária em amostra randomizada da população urbana de Pouso Alegre, Minas Gerais, Brasil. Rev. Latino-Am. 2010;18(5): 1-8. http://doi.org/10.1590/S0104-11692010000500010

8. Benício CDAV, Luz MHBA, Lopes MHBM, Carvalho NAR. Incontinência Urinária: Prevalência e Fatores de Risco em Mulheres em uma Unidade Básica de Saúde. Estima-Brazilian Journal of Enterostomal Therapy. 2016; 14 (4): 161-168. https://doi. org/10.5327/Z1806-3144201600040002 
9. Oliveira LGP, Oliveira AG de, Souza G de, Resende MA. Incontinência urinária: a atuação do profissional de enfermagem. REAS. 2018; (18):e118. https://doi.org/10.25248/reas.e118.2019

10. Benício CDAV. Avaliação do impacto de blog na autoconfiança de pacientes e cuidadores praticantes do cateterismo intermitente limpo. Tese (Doutorado em Enfermagem) - Universidade Federal do Piauí, Centro de Ciências da Saúde, Programa de PósGraduação em Enfermagem, Teresina, 2018.

11. Favoretto NB. Development of a virtual forum for people with spina bifida and their families: Collaboration and Exchange of Technology between Brazil and Germany. 2015. Tese (Doutorado em Enfermagem) - Universidade de São Paulo, Faculty of rehabilitation Sciencesat the University of Dortmund, Germany, São Paulo, 2015.

12. Silva SLA, TorresJL, Peixoto SVA. Fatores associados à busca por serviços preventivos de saúde entre adultos brasileiros: Pesquisa Nacional de Saúde, 2013. Ciênc. saúde coletiva. 2020; 25(3):783-792. https://doi.org/10.1590/1413-81232020253.15462018

13. Bitencourt GR, Felippe NHMD, Santana RF. Diagnóstico de enfermagem eliminação urinária prejudicada em idosos no pósoperatório: um estudo transversal. Rev. enferm. UERJ.2016; 24(3):e16629. https://doi.org/10.12957/reuerj.2016.16629

14. Townsend MK, Curhan GC, Grodstein F, Resnick NM. Original research: rates of renission improvement and progression of urinary incontinence in Asian, Black and White womwn, AJN The American Journal of Nursing, 2011;111(4):34-35. https://doi. org/10.1097/01.NAJ.0000396551.56254.8f

15. Instituto Brasileiro De Geografia E Estatística (IBGE). [acesso em 23 de maio de 2019] Available at: https://agenciadenoticias. ibge.gov.br/agencia-sala-de-imprensa/2013-agencia-de-noticias/releases/23852-ibge-divulga-o-rendimento-domiciliar-percapita-2018

16. Pacagnella RC, Martinez EZ, Vieira EM. Validade de construção de uma versão em português do Índice de Função Sexual Feminina. Cafajeste. Saúde Pública. 2009; 25 (11): 2333-2344. https://doi.org/10.1590/S0102-311X2009001100004

17. Oliveira JR, Garcia RR. Cinesioterapia no tratamento da incontinência urinária em mulheres idosas. Rev. bras. geriatr. gerontol. 2011; 14 (2): 343-351. https://doi.org/10.1590/\$1809-98232011000200014

18. Matos MAB, Barbosa BLA, Costa MC, Rocha FCV, Almeida CAPL, Amorim FCM. As Repercussões Causadas pela Incontinência Urinária na Qualidade de Vida do Idoso. Rev Fund Care Online.2019; 11(3):567-575. https://doi.org/10.9789/2175-5361.2019. v11i3.567-575

19. Ting HY, Cesar JÁ. Urinary incontinence among pregnant women in Southern Brazil: A population-based cross-sectional survey. PLOS ONE. 2020; 15(6): e0234338. https://doi.org/10.1371/journal.pone.0234338

20. Mourão LF, Araújo Luz MHB, Marques ADB, Vasconcelos Benício CDA, Teixeira Nunes BMV, Pereira AFM. Caracterização e fatores de risco de incontinência urinária em mulheres atendidas em uma clínica ginecológica. Estima-Brazilian Journal of Enterostomal Therapy. 2017; 15(2). https://doi.org/10.5327/Z1806-3144201700020004

21. Milsom I, Gyhagen M. The prevalence of urinary incontinence, Climacteric, 2019; 22(3): 217-222. https://doi.org/10.1080/1369 7137.2018 .1543263

22. Oliveira TM, Valdez FML, Lima KES, Magalhães MS, Abdon APV, Bezerra IN. Prevalência de Incontinência Urinária e Fatores Associados em Mulheres no Climatério em uma Unidade de Atenção Primária à Saúde. Rev Bras Promoç Saúde, 2015; 28(4): 606-612. Available at: https://periodicos.unifor.br/RBPS/article/view/5422/pdf 